\title{
The effect of low dietary manganese intake on rainbow trout (Salmo gairdneri)
}

\author{
BY D. KNOX, C. B. COWEY AND J. W. ADRON \\ Institute of Marine Biochemistry, St Fittick's Road, Aberdeen ABI 3RA
}

(Received 16 February 1981-Accepted 16 June 1981)

\footnotetext{
1. Rainbow trout (Salmo gairtmeri) of mean initial weight $15 \mathrm{~g}$ were given either a low-manganese or control diet containing 1.3 and $33 \mathrm{mg} \mathrm{Mn} / \mathrm{kg}$ dry diet respectively.

2. Weight gains over a 24-week feeding period were the same for both groups of trout.

3. Hepatosomatic index, bloot packed cell volume and haemoglobin concentration, plasma protein and the activities of aspartic aminotransferase $(E C 2.6 .1 .1)$ and alanine aminotransferase $(E C 2.6 .1 .2)$ were unaffected by dietary $\mathrm{Mn}$ intake.

4. Plasma potassium and iron levels were increased in the trout given the low-Mn diet.

5. The hepatic levels of magnesium, sodium, $\mathrm{K}$, zinc, copper, $\mathrm{Mn}$ and phosphorus were significantly reduced in the fish given the low-Mn diel.

6.In those trout given the low-Mn diet the levels of $\mathrm{Mn}$ and calcium in the vertebral ash were significantly reduced.

7. The hepatic activity of $\mathrm{Cu}-\mathrm{Zn}$ superoxide dismutase (EC 1.15.1.1; Cu-ZnSOD) and of Mn superoxide dismutase ( $E C$ 1 15 1 1 1; MnSOD) in cardiac muscle and liver was reduced in the group of trout given the low-Mn diet. The fall in $\mathrm{Cu}-\mathrm{ZnSOD}$ and $\mathrm{MnSOD}$ activities coincided with reduced tissue levels of their respective metal components.
}

Manganese deficiency in animals and man results in a wide variety of disorders which include growth retardation, skeletal deformities, impaired glucose tolerance, ataxia and defective egg shell formation (Leach, 1974). Lall \& Bishop (1977) demonstrated a dietary requirement for $\mathrm{Mn}$ in Atlantic salmon (Salmo salar) grown in sea water. More recently, while the present experiments were in progress, Ogino \& Yang (1980) showed that both carp (Cyprinus carpio) and rainbow trout (Salmo gairdneri) require dietary Mn to ensure normal growth.

The present experiment was conducted to examine the effect of dietary Mn deficiency on rainbow trout. Growth, tissue mineral levels and the activity in liver and heart of the copper-zinc superoxide dismutase (EC 1.15.1.1; Cu-ZnSOD) and of the manganese superoxide dismutase (EC 1.15.1.1; MnSOD) were examined.

Dietary Mn deficiency had no effect on the growth of rainbow trout. However, tissue Mn levels and the activity of MnSOD in heart and liver were significantly reduced. The activity of $\mathrm{Cu}-\mathrm{ZnSOD}$ was also lowered in liver.

\section{MATERIALS AND METHODS}

Rainbow trout of mean weight approximately $15 \mathrm{~g}$ were obtained from Dornoch Fisheries, Dornoch, Scotland, and randomly distributed among four circular glass-fibre tanks of diameter $1 \mathrm{~m}$, depth $0.6 \mathrm{~m}$ and each containing 4001 water (30 fish per tank). The water from the tanks was partially recirculated, with a constant bleed-in of fresh tap-water ( $751 /$ tank per $h$ ) from the city of Aberdeen domestic supply. The Mn concentration in the water during the experimental period was $3.3 \mu \mathrm{g} \mathrm{Mn} / \mathrm{l}$. The tanks were housed in an aquarium room with an ambient temperature averaging $15^{\circ}$.

The fish were given the control diet until they had acclimatized to, for example, their surroundings, feeding routine, diet and light cycle (approximately $6 \mathrm{~d}$ ). Initial weight 
Table 1. Composition $(\mathrm{g} / \mathrm{kg} d r y$ diet) of the diets given to rainbow trout (Salmo gairdneri)

\begin{tabular}{lcc}
\hline Ingredient & Basal manganese diet & Control diet \\
\hline Casein & 500 & 500 \\
Precooked starch & 200 & 200 \\
Capelin oil & 120 & 120 \\
Vitamin mix & 28 & 28 \\
Mineral mix & $114 \cdot 1$ & $114 \cdot 1$ \\
Cod liver oil & 30 & 30 \\
$\alpha$ Cellulose & 2 & 2 \\
Ascorbyl palmitate & $0 \cdot 4$ & $0 \cdot 4$ \\
BHA mix & $0 \cdot 5$ & $0 \cdot 5$ \\
Cystine & $5 \cdot 0$ & $5 \cdot 0$ \\
Mnso, $4 \mathrm{H}_{2} \mathrm{O}$ & 0 & $0 \cdot 12$ \\
Measured Mn level & $1 \cdot 3$ & $33 \cdot 0$ \\
(mg/kg dry diet) & & \\
\hline
\end{tabular}

* Supplied ( / $/ \mathrm{kg}$ dry diet): riboflavin $200 \mathrm{mg}$, pyridoxine hydrochloride $\mathbf{4 0} \mathrm{mg}$, nicotinic acid $800 \mathrm{mg}$, calcium pantothenate $280 \mathrm{mg}$, myo-inositol $4 \mathrm{~g}$, biotin $6 \mathrm{mg}$, pteroylmonoglutamic acid $15 \mathrm{mg}$, p-aminobenzoic acid $400 \mathrm{mg}$, choline chloride $8 \mathrm{~g}$, ascorbic acid $2 \mathrm{~g}$, DL- $\alpha$-tocopheryl acetate $400 \mathrm{mg}$, menaphthone $40 \mathrm{mg}$, cyanocobalamin $90 \mu \mathrm{g}$. thiamin hydrochloride $50 \mathrm{mg}$ in $\alpha$ cellulose.

$\dagger$ Supplied ( $/ \mathrm{kg}$ dry diet): calcium $\beta$-glycerophosphate $92.3 \mathrm{~g},\left(\mathrm{CH}_{3} \mathrm{COO}\right)_{2} \mathrm{Mg} .4 .47 \mathrm{~g}, \mathrm{KH}_{2} \mathrm{PO}_{4} 6.6 \mathrm{~g}$. $\mathrm{NaH}_{2} \mathrm{PO}_{4} .2 \mathrm{H}_{2} \mathrm{O} 7.5 \mathrm{~g}, \mathrm{NaCl} 2 \mathrm{~g}, \mathrm{FeSO}_{4} .7 \mathrm{H}_{2} \mathrm{O} 1 \mathrm{~g}, \mathrm{ZnSO}_{4} .7 \mathrm{H}_{2} \mathrm{O} 0.13 \mathrm{~g}, \mathrm{CuSO}_{4} .5 \mathrm{H}_{2} \mathrm{O} 39 \mathrm{mg}, \mathrm{CoSO}_{4} .7 \mathrm{H}_{2} \mathrm{O}$ $35 \mathrm{mg}, \mathrm{Al}_{2}\left(\mathrm{SO}_{4}\right)_{3} .16 \mathrm{H}_{2} \mathrm{O} 7 \mathrm{mg}, \mathrm{KI} 7 \mathrm{mg}$.

$\ddagger$ Butylated hydroxyanisole $200 \mathrm{~g} / \mathrm{l}$, propyl gallate $60 \mathrm{~g} / \mathrm{l}$, citric acid $40 \mathrm{~g} / 1$ in propylene glycol.

measurements were then made as previously described (Cowey et al. 1977), thereafter the fish were weighed every 4 weeks throughout the experiment which lasted for 24 weeks. The trout were fed to satiation four times daily $(6 \mathrm{~d} /$ week $)$ food pellets being put sparingly into each tank only so long as they were actively consumed.

The composition of the two diets used is shown in Table 1. The dry dietary ingredients were thoroughly mixed and made to a moist paste by the addition of distilled water ( $300 \mathrm{ml} / \mathrm{kg}$ dry ingredients) after which they were extruded through a commercial mincing machine from which the cutting blades had been removed. The resultant spaghetti-like diet ( $3 \mathrm{~mm}$ diameter) was freeze-dried and broken into small pieces for feeding. Duplicate tanks of fish were given either the control or the $\mathrm{Mn}$-deficient diet at a level of $20 \mathrm{~g}$ diet $/ \mathrm{kg}$ biomass of fish per $d$. The amount of food given to each tank was adjusted every 4 weeks in accordance with the measured biomass.

\section{Chemical methods}

Plasma from blood removed from the caudal vein was obtained by using tubes containing the lithium salt of heparin as anti-coagulant (LIP Ltd, Shipley, West Yorks). Liver and heart were excized from the fish, weighed and then quickly frozen in liquid nitrogen before storage at $-20^{\circ}$ until required. Vertebral samples were obtained by cutting off the tail of each trout at a point anterior to the adipose fin. The tail-back bone sample was then dropped into boiling water for $90 \mathrm{~s}$; removal of the flesh adhering to the vertebral column was thus facilitated. After drying the vertebral sample overnight at $100^{\circ}$ it was ashed and analysed. The mineral analyses of plasma, liver and vertebrae were carried out as described previously (Cowey et al. 1977).

Blood packed cell volume was determined as described by Blaxhall \& Daisley (1973). Haemoglobin levels were measured using a commercial assay kit with methaemoglobin as a standard (Sigma Chemical Company, Poole, England). Plasma aspartic aminotransferase (EC 2.6.1.1; GOT) and alanine aminotransferase (EC 2.6.1.2; GPT) were measured 
using the optimal assay conditions for trout described by D'Apollonia \& Anderson (1980). Plasma protein level was neasured using the Coomassie blue method described by Spector (1978).

Liver superoxide dismutase (SOD) was determined by the method of Heikkila et al. (1976). The liver was homogenized in 9 vol. $0.05 \mathrm{M}$-phosphate buffer, $\mathrm{pH} 7 \cdot 2$, containing Triton X-100 (10 g/1). The supernatant fraction obtained after centrifugation for $5 \mathrm{~min}$ at $12000 \mathrm{~g}$ was used in the assay. Total SOD activity i.e. $\mathrm{Cu}-\mathrm{ZnSOD}+\mathrm{MnSOD}$ was determined in the absence of cyanide. The activity of the MnSOD was measured in the presence of $5 \mathrm{~mm}$-potassium cyanide. Preliminary work showed that, at this concentration of $\mathrm{KCN}, \mathrm{Cu}-\mathrm{ZnSOD}$ activity was inhibited, thus measurement of the MnSOD activity alone was then possible by virtue of its insensitivity to $\mathrm{KCN}$.

Hearts were homogenized in buffer and centrifuged as described previously. Since factors present in the heart hornogenate stimulated the auto-oxidation of the substrate 6hydroxydopamine hydrobromide used in the liver SOD assay the method of Panchenko et al. (1975) was used. In both heart and liver SOD assay systems the protein concentration used had been shown by frevious work to be directly proportional to the enzyme activity measured. The mineral content of the heart supernatant fraction used in the SOD assay was measured after deproteinization with an equal volume of trichloroacetic acid ( $100 \mathrm{~g} / 1)$. The analysis was carried out in the same way as for plasma.

Analyses were carried out on 10 fish selected by random methods from each of the four tanks of trout i.e. 20 fish from each dietary treatment. The statistical significance of the experimental data was established by Student's $t$ tests (Fisher, 1950).

\section{RESULTS}

No gross manifestations of deficiency were observed in any of the experimental trout; growth, mortality rate and food efficiency ratio were also unaffected by the level of dietary Mn(Table 2). Similarly, the hepatosomatic index, blood packed cell volume and haemoglobin level, plasma protein concentration and the activities of plasma GOT and GPT were unaltered by the feeding of the Mn-deficient diet (Table 3).

No significant changes were found in plasma calcium, magnesium, phosphorus, sodium or zinc concentrations. However, those trout given the $\mathrm{Mn}$-deficient diet had significantly elevated levels of potassium and iron in the plasma (Table 4). The plasma Mn concentrations were too low for measurement by atomic absorption spectrophotometry.

In the liver of the $\mathrm{Mn}$-deficient trout levels of $\mathrm{Ca}$ and $\mathrm{Fe}$ were unchanged, but there were significant reductions in the hepatic concentrations of $\mathrm{Mg}, \mathrm{Na}, \mathrm{Zn}, \mathrm{Cu}, \mathrm{P}, \mathrm{K}$ and $\mathrm{Mn}$ when compared with the levels found in the livers from the fish given the control diet (Table 4).

Vertebral levels of $\mathrm{Mn}, \mathrm{Ca}$ and $\mathrm{Na}$ were significantly lower in the $\mathrm{Mn}$-deficient trout than in the control fish. Although there were small changes in the concentrations of the other ions measured, in particuliar $P$ and $F e$, the differences found between deficient and control group trout were not statistically significant (Table 4).

Mineral analysis of the supernatant fractions used in the assay of heart SOD showed that, although $\mathrm{Zn}$ and $\mathrm{Cu}$ levels were the same in both deficient and control fish, the level of Mn was significantly reduced in the Mn-deficient trout (Table 4).

Table 5 shows the SOD activities found in livers and hearts of the experimental trout. In the livers of trout given the Mn-deficient diet the activities of the $\mathrm{Cu}-\mathrm{ZnSOD}$ and the MnSOD were significantly lower than those found in the control group of fish. In the heart only the MnSOD activity was reduced in those trout given the Mn-deficient diet. 
Table 2. Total number, mean initial and final weight $(g)$, food conversion ratio (body-weight gain $(\mathrm{g}) /$ food intake $(\mathrm{g})$ and mortalities of rainbow trout (Salmo gairdneri given diets containing different amounts of manganese for 24 weeks

\begin{tabular}{cccccc}
\hline $\begin{array}{c}\text { Dietary Mn content } \\
\text { (mg/kg dry diet) }\end{array}$ & $\begin{array}{c}\text { Total no. } \\
\text { of fish }\end{array}$ & $\begin{array}{c}\text { Mean initial wt } \\
(\mathrm{g})\end{array}$ & $\begin{array}{c}\text { Mean final wt } \\
\text { (g) }\end{array}$ & $\begin{array}{c}\text { Food conversion } \\
\text { ratio }\end{array}$ & Mortalities \\
\hline 1.3 & 30 & 15.5 & 180.9 & 1.11 & 2 \\
1.3 & 30 & 16.3 & 184.0 & 1.16 & 0 \\
33.0 & 30 & 15.1 & 170.6 & 1.20 & 0 \\
33.0 & 30 & 15.7 & 189.3 & 1.05 & 3 \\
\hline
\end{tabular}

Table 3. Hepatosomatic index ([liver weight $\mathrm{g} /$ body-weight $\mathrm{g}] \times 10^{2}$ ), packed cell volume, haemoglobin $(\mathrm{g} / \mathrm{l}$ blood), plasma protein $(\mathrm{g} / \mathrm{l})$, plasma aspartic aminotransferase (EC 2.6.1.1;GOT) and alanine aminotransferase (EC 2.6.1.2;GPT) $\left(U^{*} / l\right)$ in rainbow trout (Salmo gairdneri) given diets containing different amounts of manganese $\dagger$

(Mean values with their standard errors for 20 fish/treatment)

\begin{tabular}{|c|c|c|c|c|}
\hline & \multicolumn{2}{|c|}{ Mn-deficient diet } & \multicolumn{2}{|c|}{ Control diet } \\
\hline & Mean & $\mathbf{S E}$ & Mean & SE \\
\hline Hepatosomatic index & 1.42 & 0.03 & 1.33 & 0.04 \\
\hline Packed cell volume & 44.2 & 1.0 & 42.8 & 0.9 \\
\hline Haemoglobin & 84.5 & $2 \cdot 1$ & 79.5 & $2 \cdot 2$ \\
\hline Plasma protein & 49.5 & 1.0 & $49 \cdot 5$ & $1 \cdot 3$ \\
\hline GPT & 11.0 & 1.6 & $11 \cdot 1$ & 1.6 \\
\hline GOT & 245.8 & 21.8 & 236.8 & $23 \cdot 1$ \\
\hline
\end{tabular}

* $\mu \mathrm{mol}$ NADH oxidized/min per/1 plasma.

+ For details of diets, see Table 1 .

\section{DISCUSSION}

The absence of any gross disorders or abnormal growth in those trout given the Mn-deficient diet is in contrast to the findings of Ogino \& Yang (1980). These authors showed that when rainbow trout of mean initial weight $1.5 \mathrm{~g}$ were given a diet containing $4 \mathrm{mg} \mathrm{Mn} / \mathrm{kg}$ dry diet over a period of 12 weeks the growth rate was lower than that of trout given the same diet containing $13 \mathrm{mg} \mathrm{Mn} / \mathrm{kg}$ diet. The authors also described deficiency symptoms in the Mn-deficient trout which included abnormal growth of the tail and a shortening of the body length. The Mn-deficient diet used by Ogino \& Yang (1980) contained an Mn concentration threefold that used in the present experiment. Since neither growth rate nor body length was affected by feeding this diet for 24 weeks, it may be inferred that small fish are much more sensitive to $\mathrm{Mn}$ deficiency than are larger fish and so have a greater dietary requirement per unit body-weight. This greater sensitivity to $\mathrm{Mn}$ deficiency on the part of small fish may reflect a heightened metabolic need (e.g. for bone formation) during a period of rapid growth. In the experiment described by Ogino \& Yang (1980) a ninefold increase in body-weight of small rainbow trout was achieved after 12 weeks of feeding (food conversion ratio 0.91 ). In the present experiment the increase in body-weight over a similar period was approximately fourfold with a food conversion ratio of $1 \cdot 1$. It is noteworthy that in liver, heart and vertebrae from Mn-deficient trout the concentrations of Mn were significantly lower than those found in tissues of control fish. By analogy, the requirement 


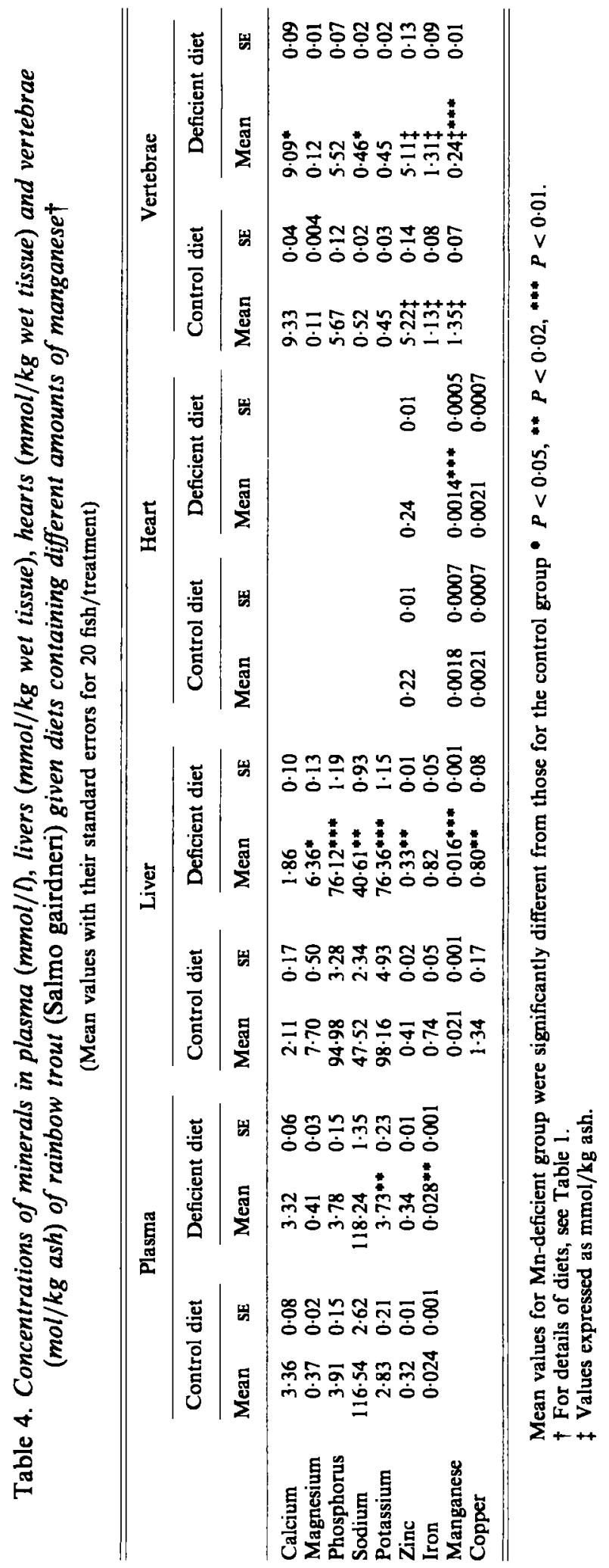


Table 5. The activities (units $\dagger / g$ tissue) of manganese superoxide dismutase (EC 1.15 .1.1; $\mathrm{MnSOD}$ ) and copper-zinc superoxide dismutase (EC 1.15.1.1;Cu-ZnSOD) in livers and hearts of rainbow trout (Salmo gairdneri) given diets containing different amounts of manganese

(Mean values with their standard errors for $20 \mathrm{fish} /$ treatment)

\begin{tabular}{|c|c|c|c|c|c|}
\hline \multirow[b]{2}{*}{ Tissue } & \multirow[b]{2}{*}{ Diet } & \multicolumn{2}{|c|}{ MnSOD } & \multicolumn{2}{|c|}{$\mathrm{Cu}-\mathrm{ZnSOD}$} \\
\hline & & Mean & $\mathbf{S E}$ & Mean & $\mathbf{S E}$ \\
\hline $\begin{array}{l}\text { Liver } \\
\text { Heart }\end{array}$ & $\begin{array}{l}\text { Mn-deficient } \\
\text { Control } \\
\text { Mn-deficient } \\
\text { Control }\end{array}$ & $\begin{array}{l}36 \cdot 1 \\
56 \cdot 0^{*} \\
26 \cdot 1 \\
60 \cdot 2^{*}\end{array}$ & $\begin{array}{l}3 \cdot 4 \\
5 \cdot 7 \\
2 \cdot 8 \\
2 \cdot 8\end{array}$ & $\begin{array}{c}686 \cdot 8 \\
798.9 * \\
60 \cdot 5 \\
54.7\end{array}$ & $\begin{array}{r}26.9 \\
25.9 \\
4.6 \\
5.8\end{array}$ \\
\hline
\end{tabular}

Mean values for $\mathrm{Mn}$-deficient group were significantly different from those for the control group $* P<0.01$. + One unit of SOD activity was defined as the amount of enzyme needed to obtain $50 \%$ inhibition of the substrate auto-oxidation.

$\ddagger$ For details of diets, see Table 1 .

of growing pigs for Mn is extremely low (Underwood, 1971) growth on diets low in Mn being maintained at the expense of tissue $\mathrm{Mn}$.

The proportions of $\mathrm{Cu}-\mathrm{ZnSOD}$ and MnSOD activity in the hearts from trout given the control diet were very similar to those found in the carp. However, in the trout livers, the proportion of MnSOD in the total hepatic SOD activity was greater than that found in carp liver (Mazeaud et al. 1979).

In the livers and hearts from the Mn-deficient trout the activity of MnSOD was significantly lower than that found in the tissues of control fish. Paynter (1980) and De Rosa et al. (1980) reported similar findings in the heart and liver of rats and mice, however, in the chicken, only the liver MnSOD activity was reduced by dietary Mn deficiency (De Rosa et al. 1980). It would therefore appear that, in common with these experimental animals, the activity of MnSOD in trout liver and heart is sensitive to the availability of the metal in the diet.

The activity of the liver $\mathrm{Cu}-\mathrm{ZnSOD}$ was also lowered in the Mn-deficient trout. This finding contrasts with those in rat liver and heart where the $\mathrm{Cu}-\mathrm{ZnSOD}$ activity was unaffected by dietary Mn intake (Paynter, 1980) and chicken liver where there was a compensatory increase in $\mathrm{Cu}-\mathrm{ZnSOD}$ as the MnSOD activity fell. This fall in $\mathrm{Cu}-\mathrm{ZnSOD}$ activity may, like the MnSOD activity changes, be linked to the reduction in hepatic levels of the metal components of the enzyme, i.e. $\mathrm{Cu}$ and $\mathrm{Zn}$. The absence of any difference between the heart $\mathrm{Cu}$ levels and $\mathrm{Cu}-\mathrm{ZnSOD}$ activity in both $\mathrm{Mn}$-deficient and control trout further supports this suggestion. Indeed Paynter et al. (1979) showed that in rat liver the activity of $\mathrm{Cu}-\mathrm{ZnSOD}$ was positively correlated with the hepatic $\mathrm{Cu}$ concentrations.

The observed changes in liver and heart mineral levels, the decrease in MnSOD activity in liver and heart and the reduced activity of $\mathrm{Cu}-\mathrm{ZnSOD}$ in liver of $\mathrm{Mn}$-deficient trout may have adverse effects under certain conditions. These enzymes remove superoxide radicals from the cell and so protect against free radical damage, for example, Mn deficiency in mice is characterized by membrane damage, the mitochondrial membranes being especially affected (Bell \& Hurley, 1973). The reduced levels of SOD found in Mn-deficient trout in the present experiment may suffice to remove superoxide radicals arising during normal metabolism; should there be any abnormal formation of these radicals (rancid fat in the diet, pesticide uptake from the water affecting the microsomal mixed-function oxidase system) then tissue damage may be initiated. 
Deformities of the bones are well known during Mn deficiency (Underwood, 1971) and such deformities have been described in Mn-deficient rainbow trout by Ogino \& Yang (1980). In the present experiment, although the vertebral Ca level was significantly reduced in the deficient fish, the $\mathrm{Cal}_{\mathrm{l}} \mathrm{P}$ value was the same in both Mn-deficient and control trout. Leach (1974) described the involvement of $\mathrm{Mn}$ in the activation of glycosyltransferases and it is possible that most of the bone deformities found in Mn deficiency are not due entirely to incomplete calcification but may also be directly related to a reduction in the products of the transferase reactions e.g. the mucopolysaccharides needed in the formation of chondroitin sulphate and hence a loss of rigidity in the bone connective tissue may occur. This may be the situation in trout since the vertebral Mn concentration was significantly lower in the Mn-deficient gl:oup of fish which suffered from bone deformities compared with the normal control group (Ogino \& Yang, 1980).

\section{REFERENCES}

Bell, L. T. \& Hurley, L. S. (1973). Lab. Invest. 29, 723.

Blaxhall, P. C. \& Daisley, K. W. (1973). J. Fish Biol. 5, 771.

Cowey, C. B., Knox, D., Adron, J. W., George, S. \& Pirie, B. (1977). Br. J. Nutr. 38, 127.

D'Apollonia, S. \& Anderson, P. D. (1980). Can. J. Fish. Aquat. Sci. 37, 163.

De Rosa, G., Keen, C. L., Leach, R. M. \& Hurley, L. S. (1980). J. Nutr. 110, 795.

Fisher, R. A. (1950). Statistical Methods for Research Workers. Edinburgh: Oliver \& Boyd.

Heikkila, R. E., Cabbat, F. S. \& Cohen, G. (1976). J. biol. Chem. 251, 2182.

Lall, S. P. \& Bishop, F. J. (1977). Fish. Mar. Serv. Res. Dev. Tech. Rep. No. 688.

Leach, R. M. (1974). Trace Element Metabolism in Animals, vol. 2, p. 51 [W. G. Hoekstra, J. W. Suttie, H. E. Ganther and W. Mertz, editors]. Baltimore University Park Press.

Mazeaud, F., Maral, J. \& Michelson, A. M. (1979). Biochem. biophys. Res. Commun. 86, 1161.

Ogino, C. \& Yang, G. Y. (1980). Bull. Jap. Soc. Scient. Fish. 46, 455.

Panchenko, L. F., Brusov, O. S., Gerasimov, A. M. \& Loktaeva, T. D. (1975). FEBS Lett. $55,84$.

Paynter, D. I. (1980). J. Nutr. 111, 437.

Paynter, D. I., Moir, R. J. \& Underwood, E. J. (1979). J. Nutr. 109, 1570.

Spector, T. (1978). Analyt. Biocht'm. 86, 142.

Underwood, E. J. (1971). Trace Eiements in Human and Animal Nutrition. 3rd ed., p. 196. New York and London: Academic Press. 